\title{
The Influence of Perception, Attitudes, and Subjective Norms on Compliance of Public Health Protocols
}

\author{
Hono Sejati ${ }^{1}$, Hutari Puji Astuti ${ }^{2}$ \\ Master of Law, Darul Islam Sudirman Guppi University, Semarang ${ }^{1}$ \\ Midwifery Department of Kusuma Husada University, Surakarta ${ }^{2}$ \\ \{honosejati89@gmail.com ${ }^{1}$, hutari.pujiastuti2508@gmail.com²
}

\begin{abstract}
Lately the world is facing global challenges which coincide with the occurrence of social crises due to the spread of the Covid-19 pandemic causing strict adherence to health protocols in social life. Therefore, people are required to have the right knowledge, perceptions and actions so that there is no transmission of Covid-19 during mobility in the community. Especially during the Covid-19 emergency, which made people have to work at home, as is happening now. This study aims to determine the correlational relationship between perceptions, attitudes, and subjective norms on compliance with health protocol implementation behavior during the Covid-19 emergency. This study uses a quantitative approach in which data is extracted through a questionnaire on the community in Semarang and Surakarta. The Likert scale was used to collect data from 200 respondents using purposive sampling technique. The research instrument used a questionnaire with 26 items / parameters adapted from Bachtiar et al (2020) and Bouteba et al (2021). Furthermore, the data were analyzed using descriptive analysis techniques and SEM.
\end{abstract}

Keywords: Perception; Attitude; Subjective Norm; Compliance Behavior

\section{Introduction}

The outbreak of the corona virus has caused all world activities to be on track. A very chaotic economy occurs, political irregularities are the impact of the domino effect of the corona virus that is happening. In Indonesia, no exception, since the government declared this a national disaster, various steps have been taken by the government as an option to overcome and reduce the impact of this corona virus [1]. Responding to the outbreak of the Corona virus or Covid 19, all layers of society work together in handling Covid-19 from the central government level to the lowest in the family sphere.

Both formal and informal employment sectors such as education, tourism, trade and transportation must work hard to adapt to the development of the Covid-19 infection. Symptoms of severe cases of Corona virus infection or (Covid-19) was : difficulty breathing, Pneumonia infection, Pain in the stomach, and decreased appetite[2]. Currently, the spread of SARS-CoV-2 from humans to humans is the main source of transmission so that the spread becomes more aggressive.SARS-CoV-2 transmission from symptomatic patients occurs via droplets that are released when coughing or sneezing [3]. 
Various ways have been made, starting from the making of policies that involve collecting or doing activities with a large number of people, for example the application of social distancing by limiting visits to crowded places and making direct contact with other people. One of the methods used to implement social distancing is by working from home or the Work Form Home [4].

Government policies to cope with and prevent more widespread transmission of Covid-19, including through Government Regulation Number 21 of 2020 dated March 31, 2020, the government establishes Large-Scale Social Restrictions (PSBB) in order to accelerate the handling of Corona Virus Disease 2019 (Covid-19).This policy is based on Law Number 6 of 2018 concerning Health Quarantine.This policy was first implemented in Jakarta on April 10, 2020, as the initial epicenter of Covid-19 in Indonesia [5].

In addition to implementing the PSBB, the government also implements an appeal to the community about the main steps that the community wants to take, such as wearing masks;covering the mouth and nose when sneezing or coughing;regular hand washing with soap or disinfection with a hand sanitizer containing at least $60 \%$ alcohol;avoiding contact with infected people;keep a distance from people;and refrain from touching the eyes, nose, and mouth with unwashed hands [6].

The existence of the WFH policy causes people's income to decrease drastically, because it is very rare for people to work at the office, school children are closed because schools are temporarily closed since the implementation of Work From Home, or learning from home, so traders who usually sell their wares at work / school do not can again market their wares so that the income is greatly decreased or insufficient [7].

The policy for implementing this health protocol was formed to reduce the increase and spread of Covid-19 in certain areas. As a result of the continued increase in Covid-19 cases in these areas, it can be caused by the disobedience of the community in implementing health protocols. Compliance is closely related to behavior. According to Lawrence Green, behavior is caused by three factors, namely predisposing factors, enabling factors and driving factors. This theory studies human behavior in terms of health and as a health planning tool [8].

This policy was greeted with various reactions, some responded positively and others doubted whether WFH could be implemented effectively, given its sudden implementation and the possibility that the community was not ready for this policy and also the lack of other supporting facilities.From Home, which has been in effect since the Corona outbreak occurred, the public will accept the impact, because not all people are ready for this kind of situation, many of the people do not have savings, their economy is also threatened. Every patient under surveillance, person under surveillance, or probable should have an epidemiological investigation.Epidemiological investigation activities are carried out mainly to find close contacts. The results of epidemiological investigations can provide input to policy makers in order to respond more quickly [9].

Research on the assimilation of industry players' compliance with the implementation of health protocol policies in Semarang and Surakarta City government has never been conducted.In fact, research on the assimilation of industry players' compliance with the implementation of health protocol policies is very important in order to provide feedback for the government as a stakeholder for the entire community. 


\section{Methods Research}

This research is a descriptive qualitative research type because it describes the facts or characteristics of a certain population by interpreting and analyzing data in the form of descriptions based on conditions and realities in the field. The accidental sampling technique was used by determining a sample of 120 respondents using public transportation in the Cirebon, Indramayu, Majalengka, and Kuningan areas. The questionnaire instrument with a Likert scale was adapted from Bachtiar et al (2020), and Bouteba et al (2021) to collect research data. SEM technique used WARP-PLS to analyze this research data. untuk mengumpulkan data penelitian. Teknik SEM digunakan WARP-PLS untuk menganalisis data penelitian ini [10].

\section{Result and Discussion}

According to Ghozali (2014), Goodness of fit measures the suitability of observational / actual inputs, with the prediction of the proposed model. There are 3 criteria for model fit indices or model suitability, namely the Average Path Coefficient (APC), Average R-square (ARS) and Average Variant Inflation Factor (AVIF). Following are the results of the fit Model output:

Table 1. Model Fit

\begin{tabular}{ccc}
\multicolumn{3}{c}{ Table 1. Model Fit } \\
\hline Model & Fit Indices & $\mathbf{P ~ V a l u e s}$ \\
\hline APC & 0.352 & $\mathrm{P}<0.001$ \\
ARS & 0.627 & $\mathrm{P}=0.001$ \\
AVIF & 2.104 & Good If $<0.5$ \\
\hline
\end{tabular}

From the output results in table 1 shows that the model indicator is fit with an average path coefficient (APC) $0.001<0.05$. While the Average R-squared (ARS) $0.001<0.05$. Likewise, the AVIF value is $2.104<5$, which means that the model has a good fit so that there is no multicollinearity problem between exogenous variables. Convergent Validity Test Convergent validity is assessed based on the correlation between the indicator score and the construct score (outer loading). According to Chin (1998), each indicator can be said to be valid if its outer loading value is greater than 0.7 . However, for research in the early stages of developing a measurement scale the loading value of 0.60 is considered sufficient (Ghozali, 2014). If an indicator does not meet these criteria, then the indicator is declared invalid and needs to be removed from the model.

Table 2. Outer Loading Value

\begin{tabular}{ccccc}
\hline & Perception & Attitude & Subnorm & Behavior \\
\hline X1.1 & $\mathbf{0 . 7 9 4}$ & 0.183 & -0.050 & -0.607 \\
X1.2 & $\mathbf{0 . 5 7 3}$ & -0.233 & 0.244 & 0.982 \\
X1.3 & $\mathbf{0 . 8 4 3}$ & -0.015 & -0.119 & -0.096 \\
X2.1 & 0.331 & $\mathbf{0 . 7 4 1}$ & -0.141 & 0.051 \\
X2.2 & -0.149 & $\mathbf{0 . 8 1 6}$ & -0.084 & 0.328 \\
X2.3 & -0.168 & $\mathbf{0 . 8 4 2}$ & -0.132 & 0.011 \\
X2.4 & 0.021 & $\mathbf{0 . 8 4 5}$ & 0.337 & -0.373 \\
X3.1 & 0.021 & 0.864 & $\mathbf{0 . 7 7 8}$ & -0.373 \\
X3.2 & 0.193 & -0.708 & $\mathbf{0 . 7 2 1}$ & 0.188 \\
X3.3 & -0.025 & -0.853 & $\mathbf{0 . 7 0 5}$ & 0.355 \\
X3.4 & -0.184 & 0.586 & $\mathbf{0 . 7 4 9}$ & -0.127 \\
Y1 & 0.273 & -0.175 & 0.359 & $\mathbf{0 . 5 6 1}$ \\
\hline
\end{tabular}




\begin{tabular}{ccccc}
\hline & Perception & Attitude & Subnorm & Behavior \\
\hline Y2 & 0.014 & 0.321 & -0.295 & $\mathbf{0 . 8 5 4}$ \\
Y3 & -0.027 & 0.011 & -0.182 & $\mathbf{0 . 7 8 6}$ \\
Y4 & -0.181 & -0.233 & 0.244 & $\mathbf{0 . 7 9 2}$ \\
\hline
\end{tabular}

Table 2 shows that all indicators have an outer loading value of more than 0.5 , so all indicators are valid so that they can be continued for further data analysis. A construct is said to be reliable as seen from its composite reliability value and Cronbach's alpha value. The construct is declared reliable if the composite reliability value of Ununcronbach's alpha is above 0.70. (Ghozali, 2014).

Table 3. Reliability Test

\begin{tabular}{lcccc}
\hline \multicolumn{1}{c}{ Variabel } & Composite Reliability & Cronbach's Alpha & AVE & Keterangan \\
\hline Perception (X1) & 0.786 & 0.590 & 0.557 & Reliable \\
Attitude (X2) & 0.885 & 0.827 & 0.659 & Reliable \\
Subjective Norm (X3) & 0.828 & 0.723 & 0.546 & Reliable \\
Behavior (Y) & 0.840 & 0.742 & 0.572 & Reliable \\
\hline
\end{tabular}

Based on Table 3, it shows that the Composite Reliability value is more than 0.7 , so it can be concluded that the research instrument above is reliable. Then in the reliability test it is necessary to look at the average variances extrach (AVE) value $>0.5$. The output results are in accordance with the requirements.

\section{Inner Model}

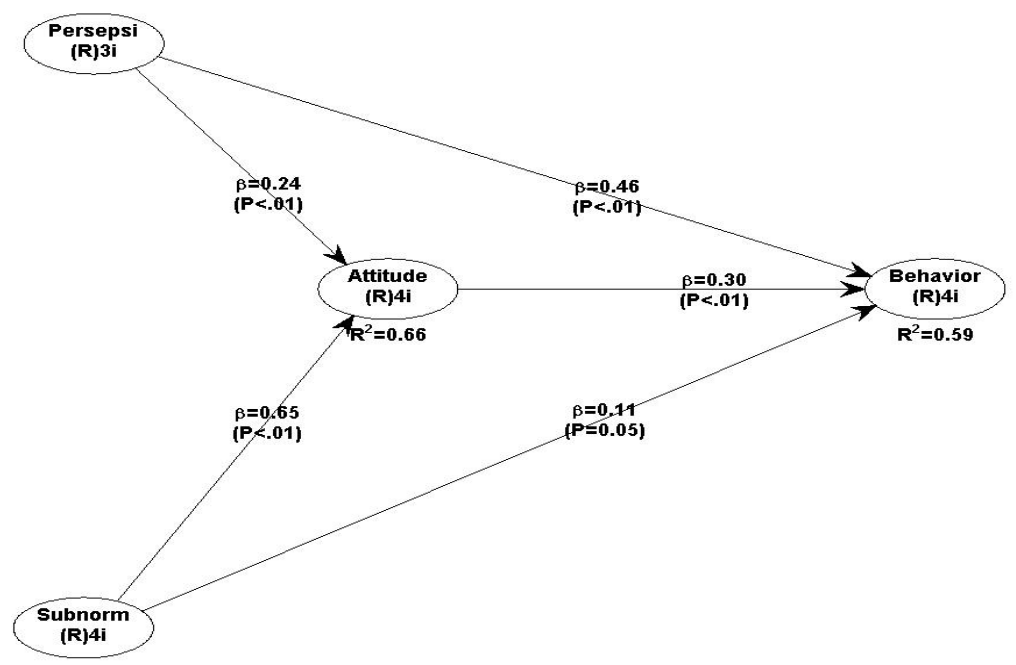

Fig. 1. Path Coefficient dan P Value

Tabel 4. Path Coefficient dan $P$ Values

\begin{tabular}{lccc}
\hline \multicolumn{1}{c}{ Correlation } & Path Coefficient & P-values & Information \\
\hline Perception $\rightarrow$ Attitude & 0.241 & $<0.001$ & Accepted \\
Subjective norm $\rightarrow$ Attitude & 0.646 & $<0.001$ & Accepted \\
Perception $\rightarrow$ Behavior & 0.465 & $<0.001$ & Accepted \\
Subjective norm $\rightarrow$ Behavior & 0.111 & 0.055 & Rejected \\
Attitude $\rightarrow$ Behavior & 0.296 & $<0.001$ & Accepted \\
\hline
\end{tabular}


The following is a description of the results of hypothesis testing which can be explained as follows:

a. Testing H1 Perception affects Attitude. The results of the calculations in table 4 show that the resulting P-values are $0.001<0.05$ and the path coefficient is 0.241 which is positive. $\mathrm{p}$ value of 0.001 is smaller than 0.05 which means significant, meaning that $\mathrm{H} 1$ is accepted.

b. Testing Subjective Norm H2 affects Attitude. The results of the calculations in table 4 show that the resulting $\mathrm{P}$-values are $0.001<0.05$ and the path coefficient 0.646 is positive. $\mathrm{p}$ value of 0.001 is smaller than 0.05 which means significant, meaning that $\mathrm{H} 2$ is accepted.

c. Testing H3 Perception affects Behavior. The results of the calculations in table 4 show that the resulting P-values are $0.001<0.05$ and the path coefficient is 0.465 which is positive. $\mathrm{p}$ value of 0.001 is smaller than 0.05 which means significant, meaning that $\mathrm{H} 3$ is accepted

d. Testing H4 Subjective norm affects Behavior. The calculation results in table 4 show that the resulting P-values are $0.055>0.05$ and the path coefficient is 0.111 which is positive. $p$ value of 0.055 is greater than 0.05 , which means it is not significant, meaning that $\mathrm{H} 4$ is rejected.

e. Testing H5 Attitude affects the Behavior. The results of the calculations in table 4 show that the resulting $\mathrm{P}$-values are $0.001<0.05$ and the path coefficient is 0.296 which are positive. $\mathrm{p}$ value of 0.001 is smaller than 0.05 which means significant, meaning that $\mathrm{H} 5$ is accepted.

f. The coefficient of determination is described as follows:

Table 5. R-squared

\begin{tabular}{cccc}
\hline Perception & Subjective norm & Attitude & Behavior \\
\hline & & 0.661 & 0.596 \\
\hline
\end{tabular}

Based on the output results in table 5, it is obtained that the $\mathrm{R}$ squared value is 0.596 which means that the influence of perception (X1), Subjective norm impact (X2), and Attitude (X3) variables on the behavior to comply with the implementation of health protocols is $59.6 \%$ and the remaining $40,4 \%$ is influenced by other variables outside of this research model. The results of this study are in accordance with the theory of Literature on past pandemics and current COVID-19 highlights the importance of public perceptions in influencing the adoption of preventive behaviors [11]. The results of this study are also in accordance with research [12] which states that intervention steps are to reduce contact or reduce the risk of transmission (washing hands, wearing face masks). The rigor of interventions taken by different countries ranges from somewhat lenient action relying on a series of recommendations for lockdowns or government surveillance.

\section{Conclusion}

Based on the results of the research and discussion, it was can concluded that: (1) Perception has a significant effect on people's attitudes so that the first research hypothesis is accepted (2) Subjective norm has a significant effect on people's attitudes so that the second research hypothesis is accepted. (3) Perception has a significant effect on the behavior to comply with health protocols, so that the third research hypothesis is accepted. (4) Subjective norms have no significant effect on the behavior to comply with health protocols so that the 
fourth research hypothesis is rejected (5) Attitude has a significant effect on the behavior to comply with health protocols so that the fifth hypothesis is accepted.

\section{References}

[1] A. A. Wurnasari, M. D. Larasati, R. Fortunata, and ..., "Dampak Asimilasi Narapidana Terhadap Maraknya Kriminalitas Di Tengah Pandemi Covid-19," Pros. ..., pp. 20-26, 2020, [Online]. Available: http://ojs.udb.ac.id/index.php/HUBISINTEK/article/view/973.

[2] K. Karyono, R. Rohadin, and D. Indriyani, "Penanganan Dan Pencegahan Pandemi Wabah Virus Corona (Covid-19) Kabupaten Indramayu," J. Kolaborasi Resolusi Konflik, vol. 2, no. 2, p. 164, 2020, doi: 10.24198/jkrk.v2i2.29127.

[3] A. Susilo et al., "Coronavirus Disease 2019: Tinjauan Literatur Terkini Coronavirus Disease 2019: Review of Current Literatures," J. Penyakit Dalam Indones., vol. 7, no. 1, pp. 45-67, 2020.

[4] R. WD Tuti, "Analisis Implementasi Kebijakan Work From Home Pada Kesejahteraan Driver Transportasi Online di Indonesia," Transparansi J. Ilm. Ilmu Adm., vol. 3, no. 1, pp. 73-85, 2020, doi: 10.31334/transparansi.v3i1.890.

[5] I. Sulhin, "Covid-19, Pemenjaraan Berlebihan, Dan Potensi Katastrofe Kemanusiaan," J. Huk. Pembang., vol. 50, no. 2, p. 400, 2020, doi: 10.21143/jhp.vol50.no2.2588.

[6] N. P. E. D. Yanti, I. M. A. D. P. Nugraha, G. A. Wisnawa, N. P. D. Agustina, and N. P. A. Diantari, "Gambaran Pengetahuan Masyarakat tentang Covid-19 dan Perilaku Masyarakat di Masa Pandemi Covid-19," J. Keperawatan Jiwa, vol. Vol. 8 No., no. 3, pp. 485-490, 2020.

[7] A. Ristyawati, "Efektifitas Kebijakan Pembatasan Sosial Berskala Besar Dalam Masa Pandemi Corona Virus 2019 oleh Pemerintah Sesuai Amanat UUD NRI Tahun 1945," Adm. Law Gov. J., vol. 3, no. 2, pp. 240-249, 2020, doi: 10.14710/alj.v3i2.240-249.

[8] Wiranti, A. Sriatmi, and W. Kusumastuti, "Determinan kepatuhan masyarakat Kota Depok terhadap kebijakan pembatasan sosial berskala besar dalam pencegahan COVID-19,” J. Kebijak. Kesehat. Indones., vol. 09, no. 03, pp. 117-124, 2020.

[9] D. Indriyani and C. Virus, "PENANGANAN DAN PENCEGAHAN PANDEMI WABAH VIRUS CORONA ( COVID-19)," vol. 2, 2020.

[10] J. F. Hair, C. M. Ringle, and M. Sarstedt, "PLS-SEM: Indeed a silver bullet," J. Mark. Theory Pract., vol. 19, no. 2, pp. 139-152, 2011, doi: 10.2753/MTP1069-6679190202.

[11] S. Ozdemir, S. Ng, I. Chaudhry, and E. A. Finkelstein, "Adoption of Preventive Behaviour Strategies and Public Perceptions About COVID-19 in Singapore," Int. J. Heal. Policy Manag., no. x, pp. 1-13, 2020, doi: 10.34172/ijhpm.2020.199.

[12] G. Wallentin, D. Kaziyeva, and E. Reibersdorfer-Adelsberger, "Covid-19 intervention scenarios for a long-term disease management," Int. J. Heal. Policy Manag., vol. 9, no. 12, pp. 508-516, 2020, doi: 10.34172/ijhpm.2020.130. 